DOI https://doi.org/10.18551/rjoas.2017-08.26

\title{
DYNAMIC CAPABILITIES AND CREATING ORGANIZATIONAL KNOWLEDGE: IMPORTANT LINKAGE FOR BUILDING COMPETITIVE ADVANTAGE
}

\author{
Arif Sugiono* \\ Doctoral Candidate of Business Administration, University of Padjadjaran, Indonesia
}

\author{
Ria Arifianti, Sam'un Jaja Raharja, Erna Maulina \\ Business Administration Department, University of Padjadjaran, Indonesia
}

\author{
Yudith Diah Hapsari \\ Management Department, Faculty of Economics, University of Katolik Atma Jaya, Indonesia
}

*E-mail: arifsugiono01@gmail.com

\begin{abstract}
As a concept derived from the resource-based view, dynamic capabilities essentially have an important linkage with activities related to the creation of organizational knowledge. Using literature study method, this paper aims to discuss the linkage between the creation of dynamic knowledge capabilities and the creation of knowledge company. The study shows that the discussion of dynamic capabilities creation finally puts both learning and knowledge in an important position. Correspondingly, the relationship between a growth strategy that is generally chosen by the organization brings a consequence that the creation of organizational knowledge becomes something that can not be ignored. In order to make the process of knowledge creation in line with dynamic capabilities creation within a growth strategy creation framework, we need a dynamic process of knowledge creation. Among the various models of knowledge creation, $\mathrm{SECl}$ model still becomes a relevant model within organizational knowledge creation framework. In general, this study is still theoretical, therefore, more empirical subsequent discussions are expected.
\end{abstract}

\section{KEY WORDS}

Dynamic capabilities, knowledge, company.

Every organization has resources consisting of human resources, physical resources, organizational resources, and financial resources. Barney \& Clark (2007) affirmed that good resource management will take a firm achieves a competitive advantage. However, these resources should have several characteristics such as Vrin which is valuable, rare, and immutable. However, firm capability does not guarantee that an organization will be able to adapt continuously amidst the ever-changing dynamics of the environment. Therefore, a dynamic capability is required to have a successful business. (Simon, 2010).

Basically, a resource-based view is used to explain the success or failure of a company to build competitive advantage through the diversity of resources which are generally owned by a company in the midst of environmental dynamics occurred. Armed with resources owned, every organization has a capability that is generally in the form of operational capabilities used to perform everyday activities of the company in order to build a sustainable competitive advantage. (Barney, 1991; Grant, 1991; Peteraf, 1993; Teece, et.al, 1997; Simon, 2010; Parayitam \& Gharna 2010; Ahenkora \& Aedji, 2012; Tseng \& Lee, 2012).

The dynamic of environmental change has brought consequences that the success of the company is due to the company's ability to create dynamic capability characterized by its ability to maintain appropriate capabilities to the dynamic environment through a systematic and continuous learning process. A dynamic capability is an approach that can explain a company's success in building competitive advantages in the midst of rapid environmental change (Esterby et al., 2009; Ahenkora \& Aedji, 2012; Tsheng \& Lee, 2012). In contrast, the failure to create sustainable competitive advantage, amidst the rapid environmental 
dynamics and hyper competitive competition, is largely due to the inability of the company to create a competitive strategy based on resources that are not merely routine but dynamic capabilities to take advantage of available opportunities. In other words, the company is only focused on a patterned, repetitive, and non-innovative activity so that the market forces become weak (Leonard \& Barton, 1992; Winter, 2003)

Dynamic Capabilities and Knowledge Activity. In the discussion of dynamic capabilities creation, most researchers place their learning and knowledge into something important (Zollo \& Winter, 2002; McGiard \& Gordon, 2010; Lewin and Massini; 2004; Soo, et al, 2004; Gourlay, 2004; Haefliger \& Krogh , 2004; Chen \& Huang, 2012). Referring to the researcher's discussion above, the understanding of dynamic capabilities from knowledge perspective becomes important. In conclusion, similar to what is presented by Kianto \& Ritala (2010) by looking at the study of dynamic capabilities from the perspective of knowledge, the discussion of dynamic capabilities can be conceptualized as an effort to make organizational knowledge functioned as something that works to enlarge, develop, and update the system of the company. Within this framework, knowledge is an important resource for an organization which can be gained through learning mechanisms.

Furthermore, Kianto \& Ritala (2010) said that knowledge perspective, in relation to dynamic capabilities, is able to bring the organization on higher order capacity. They also assert that departing from the literature study of knowledge, there are three very fundamental reasons on why knowledge can be the basis for a company in the creation of dynamic capabilities to follow the dynamics of the environment. Those three fundamental reasons include: (i). Connectivity means that knowledge mechanism takes place in the context of existing social relationships and available social constellations which significantly influence the possibilities and the potential for knowledge development (Cohen \& Levinthal, 1990; Brown \& Duguid, 1991; Nonaka \& Takeuchi, 1995). (ii). Learning is an essential mechanism that allows the organization to develop and update its capabilities. Therefore, the learning culture can be defined as the organizational capacity which serves to develop a more flexible and adaptable way as another form of dynamic capabilities (March 1991; Zollo \& Winter; 2002; Ferdinand et al., 2004). (iii). Although knowledge can not be fully managed, the possibilities of development and exploitation can be enhanced through the provision of various means of communication technology and various forms of information system to support, enhance, and provide knowledge for its development (Sher \& Lee, 2004; Nielsen, 2006; Capeda \& Vera, 2007).

Organization Strategy and Knowledge Activity. As a consequence of the importance of knowledge for the creation of dynamic capabilities, dynamic capabilities are part of the strategic management process in formulating an organizational strategy. Besides that, discussing the linkages between the chosen strategy and the activities related to knowledge also becomes relevant. There is a link between knowledge-related activities in an organization and strategies chosen by an organization (Ichijo, 2007). Therefore, analyzing what kind of appropriate strategy for the company is a must and this step can not be ignored. To ensure the accuracy of the strategy chosen, a company strategy model developed by Wheelen \& Hunger $(1990,2000)$ can be used. This corporate strategy model offers nine options of strategies based on 2 dimensions (the vertical dimension indicates industry attractiveness while the horizontal dimension indicates the strength of the business or the competitive position of the organization) which can be seen in Table 1 below.

Among the various options of strategies above, growth strategy, in general, becomes the choice of managers. Therefore, they generally always trying to improve the strength/position of their business by using various ways. The main reasons why the growth strategy becomes the choice of business people are: (I). The bigger the better/more efficient because growth is positively correlated with economies of scale; (li). Growth increases the likelihood of survival; (lii). Growth is defined as a synonym of effectiveness and is identical to power (Robbins, 1990). The importance of the growth of a firm can also be seen from a macro and micro perspective. In a macro perspective, the growth of a firm is identical to employment provision which labor absorption acts as a result (Acs \& Armington, 2006). 
Meanwhile, in the micro perspective, the key indicators of a firm are that the products are accepted by the market and the hallmark of the business's success. (Gilbert, B.A.et.al, 2006)

Table 1 - Model of Corporate Strategies

\begin{tabular}{|c|c|c|c|c|}
\hline & \multicolumn{3}{|c|}{$\begin{array}{l}\text { Business Strengths/ } \\
\text { Competitive Position }\end{array}$} \\
\hline & & Strong & Average & Weak \\
\hline \multirow{3}{*}{ 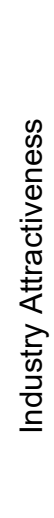 } & $\frac{\text { 음 }}{\text { ำ }}$ & $\begin{array}{c}\text { Growth } \\
\text { Concentration via Vertical } \\
\text { Integration }\end{array}$ & $\begin{array}{c}\text { Growth } \\
\text { Concentration via Horizontal } \\
\text { Integration }\end{array}$ & $\begin{array}{l}\text { Retrenchment } \\
\text { turned around }\end{array}$ \\
\hline & $\begin{array}{l}\frac{\varepsilon}{3} \\
\frac{2}{0} \\
\frac{1}{2}\end{array}$ & $\begin{array}{c}\text { Stability } \\
\text { (Pause or Proceed with Caution) }\end{array}$ & $\begin{array}{c}\text { Growth } \\
\begin{array}{c}\text { Concentration via Horizontal } \\
\text { Integration }\end{array} \\
\text { No Change or Profit Strategy }\end{array}$ & $\begin{array}{c}\text { Retrenchment } \\
\text { Captive Company or selling } \\
\text { out }\end{array}$ \\
\hline & 3 & $\begin{array}{c}\text { Growth } \\
\text { Concentric Diversification }\end{array}$ & $\begin{array}{c}\text { Growth } \\
\text { Conglomerate Diversification }\end{array}$ & $\begin{array}{c}\text { Retrenchment } \\
\text { Bankruptcy or Liquidation }\end{array}$ \\
\hline
\end{tabular}

Source: Wheleen \& Hunger (2005).

In line with the concept as stated above, Ichijo $(2006,2007)$ connects the strategies taken by the organization and the organization's activities related to the knowledge. If an organization chooses a survival strategy, the implications of the organization's activity on knowledge are more oriented on knowledge sharing and knowledge protection. However, if the strategy was chosen is a growth-oriented strategy, growth/advancement, the implications are more on knowledge creation, knowledge protection, and knowledge discarding. Table 1 shows more details of the strategic framework.

Table 2 - Strategic Framework for Knowledge

\begin{tabular}{|c|c|c|c|c|c|}
\hline Strategy & $\begin{array}{l}\text { Competitive } \\
\text { Advantage }\end{array}$ & $\begin{array}{c}\text { Sources of } \\
\text { Competitive } \\
\text { Advantage }\end{array}$ & Role of Knowledge & $\begin{array}{c}\text { Important } \\
\text { Knowledge } \\
\text { Activity }\end{array}$ & Result \\
\hline Survival & $\begin{array}{c}\text { Current } \\
\text { profitability } \\
\text { Not implemented } \\
\text { by competitors } \\
\text { Those who try } \\
\text { cannot replicate } \\
\text { the original } \\
\text { advantages }\end{array}$ & $\begin{array}{l}\begin{array}{c}\text { Economies } \\
\text { of Scale }\end{array} \\
\text { Economies of } \\
\text { Scope }\end{array}$ & $\begin{array}{l}\text { Valuable, difficult to } \\
\text { imitate, difficult to } \\
\text { substitute } \\
\text { Exclusively held or } \\
\text { in public } \\
\text { The ability to } \\
\text { transfer may more } \\
\text { important than the } \\
\text { content }\end{array}$ & $\begin{array}{l}\text { Knowledge } \\
\text { Sharing } \\
\text { Knowledge } \\
\text { Protection }\end{array}$ & $\begin{array}{l}\text { Profitability is } \\
\text { higher than the } \\
\text { average of the } \\
\text { industry }\end{array}$ \\
\hline Advancement & $\begin{array}{c}\text { Future } \\
\text { profitability } \\
\text { Not implemented } \\
\text { by competitors } \\
\text { Those who try } \\
\text { cannot replicate } \\
\text { the original } \\
\text { advantages }\end{array}$ & $\begin{array}{c}\text { Potential } \\
\text { economic of scale } \\
\\
\text { Potential } \\
\text { economies of } \\
\text { Scope } \\
\text { Potential } \\
\text { product/service } \\
\text { differentiation }\end{array}$ & $\begin{array}{l}\text { New knowledge for } \\
\text { process/product } \\
\text { innovation } \\
\text { Transferable new } \\
\text { knowledge }\end{array}$ & $\begin{array}{l}\text { Knowledge } \\
\text { creation } \\
\text { Knowledge } \\
\text { protection } \\
\text { Knowledge } \\
\text { discarding }\end{array}$ & $\begin{array}{c}\text { Future } \\
\text { profitability is } \\
\text { higher than the } \\
\text { average of the } \\
\text { industry. }\end{array}$ \\
\hline
\end{tabular}

Source: Ichijo (2006, 2007). 
The importance of the learning process in relation to activities related to the creation of knowledge in the creation of dynamic capabilities process and growth chosen by the organization has given rise to an increasingly strong assumption that knowledge is a key for a company to build a sustainable competitive advantage. (Nonaka, 1994; Nelson, 1991; Leonard \& Barton, 1995; Nonaka \& Takeuchi, 1995, Grant, 1996, Nonaka et.al 2008). The discussions about the contribution of knowledge to an organization have also been made by many parties with different perspectives including the discussion of the role of knowledge management in relation to the concept of knowledge creation (Glisbi \& Holden, 2003), the creation of knowledge company in the transition era (Gorman, 2004), knowledge management for technological innovation in organization (Heffner, 2006), the utilization of knowledge management system in automotive companies (Keki, 2008), the prospect of creating future knowledge (Chen\&Huang,2013), the value chain of knowledge management and its relation to quality management (Salajeghe, 2014).

Therefore, as a follow-up to the implementation of the strategic management model and the strategic framework for activities related to the creation of dynamic capabilities, the concept of knowledge creation becomes unavoidable within the framework of the dynamic capabilities creation. Thus, the discussion of knowledge creating concept becomes relevant for the discussion. In describing the concept of knowledge creation, SECI theory developed by Nonaka and Takeuchi (1995) is still relevant to be discussed. This model provides a philosophical foundation that is clearer and provides complete ontological and epistemological dimensions besides other theories.

Philosophically, this theory was born because it wanted to confront the traditional view which placed the organization in static and passive position and tended to be mechanistic, monotonous from day to day, used the pattern of command and control leadership as the recipient and processor of information, soil, material and energy as energy source, hierarchical structures, authority is in producers and is generally constraints in capital. The traditional view puts the organization to be more than a system that processes information or solves the problem. Traditional view asserted that the main function of the organization is to make an efficient and effective process of information and decision management in an uncertain environment. This paradigm attempts to be "criticized" by Nonaka (1994) as a passive and static paradigm since the hierarchy of its input-process-output solutions depends heavily on obtaining information obtained instead of creating information.

Seen from the ontological dimension, the creation of knowledge developed by Nonaka et al., (1995) explains that the creation of knowledge begins with the role of the individual where the creation of organizational knowledge should be interpreted as a process of creating individual/employee's knowledge, organized, managed, and crystallized through an organizational process. In its development, Nonaka et al., (2008) developed the SECI model within the framework of knowledge creation by placing individuals (individual recognition), organization, and the environment in a dialectical process that sustainably combines and moves through the SECI spiral rooted in the conversion between tacit and explicit. On the other hand, the epistemological dimension shows that there are differences and interactions between two types of knowledge namely tacit knowledge and explicit knowledge.

In other terms, the above explanation is metaphorically called as a bio-management. Thereby, the organization must become a model that is a living creature doing a biological activity to maintain its existence within the sense that mimics the way living creatures feed themselves (Sawidji, 2009). The consequence of the above metaphor is that the organization will be more defined as an organism and its ecosystem or living organism, along with its autonomous leadership patterns for employees, placing information and science as a source of value, independent organizational structure, placing the consumer as an economic authority (market was driven), and creativity as a general constraint.

In its development, Nonaka et al., (2008) developed an SECl-based dynamic model (Socialization, Externalization, Combination, and Internalization) which illustrates the various factors that influence the knowledge creation process. This model is dynamic because it involves a sustainable blend of real and abstract experiences in a specific context to build a universal theory by not forgetting the dynamic interaction in the environment. Figure 2 shows 
that this model consists of seven basic components that provide direction and energy into the $\mathrm{SECl}$ process. The seven basic components are SECl process itself, knowledge vision, driving objective, dialogue and practice, place/location in the physical/virtual sense to interact, knowledge assets, and the environment.

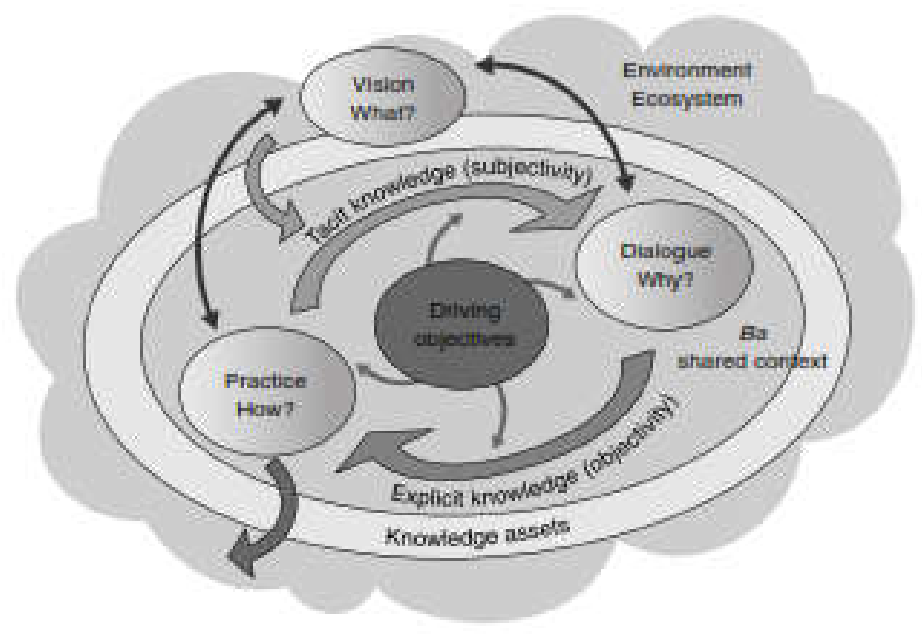

Source: Nonaka, et.al (2008)

Figure 1 - Process of the Knowledge-based firm

Bratinau \& Orzea (2010) also presented an overview of the state-of-the-art of organizational knowledge creation theory. In their description, there are at least four models of knowledge creation that they described. The four models consist of Nonaka model, Nissen model, Boisot model, and EO-SECl model. Three (Nissen model, Boisot model, and EO SECl model) out of the four models are basically the result of the model developed by Nonaka with different pressure points

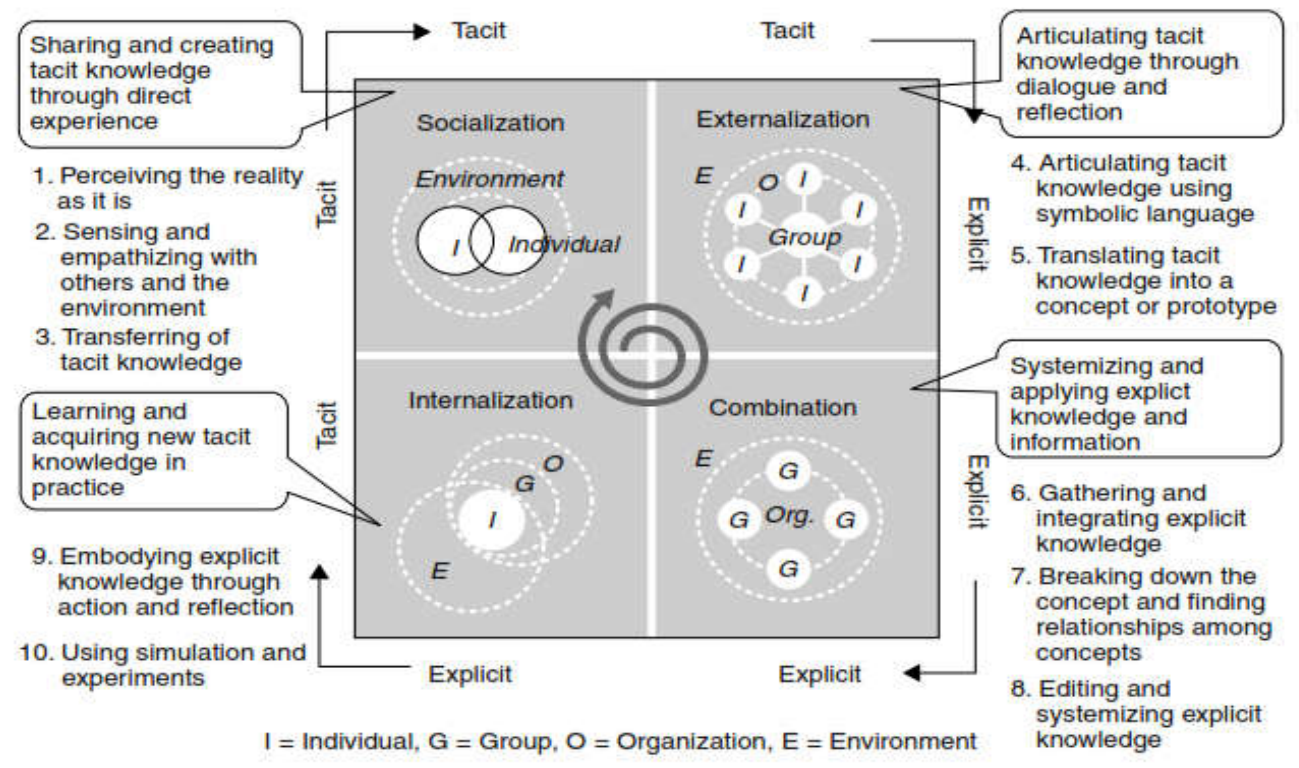

Source: Nonaka dan Toyama 2003, Nonaka et al, (2008)

Figure 2 - SECI Model for the Creation of Corporate Knowledge

If the dynamic of knowledge conveyed by Nonaka is based on the conversion of knowledge through social interaction, this will be different with the model of Nissen (2006) 
who argue that the dynamics of knowledge are based on flowing ideas. That opinion departs from an assumption that a firm is a place where knowledge flows continuously toward some direction and moves through the organization. In the context of organizational performance, the flow of knowledge lies and moves in the critical path of work that allows them to flow (Nissen, 2006). Nissen, basically, takes two models developed by Nonaka (epistemology and ontology) and adds two new dimensions namely life cycle and time flow. The life cycle refers to the different sequences of activities related to the flow of knowledge, such as the creation of knowledge, the spread of knowledge, and the use of knowledge. Meanwhile, time flow refers to the time duration expressed in minutes, days, or years of knowledge required to move from one person, organization, place or time to another (Nissen, 2006).

Moreover, Castro et al., (2007), also developed a more dynamic knowledge creation model that is EO-SECI Knowledge. Basically, this model is the development of Nonaka model, SECl, by considering the two dimensions (epistemology and ontology) which are dynamically linked at four different levels: individuals, groups, organizations, and inter organizational. The name of this model comes from: E-epistemological dimension; Oontological dimension; S-socialization; E-externalization; C-combination; I-internalization.

Furthermore, a more abstract knowledge creation model was developed by Boisot, 1999 in Bratinu \& Orzea (2010) that is based on information theory supported by l-space as a generic domain characterized by three dimensions: codification, abstraction, and diffusion. I-Space is a conceptual framework that shows information and the flow of knowledge in a group of people or organizations with respect to the three dimensions above: codification, abstraction, and diffusion. For example, the flow of knowledge towards more abstraction and codification will show greater availability to a particular population with the fact that all other things are considered the same. This I-Space model helps us to understand the creation and dissemination of new knowledge within the organization more easily as well as to understand the way it works depicted by the social learning cycle.

This cycle consists of six major phases (sequential): The first cycle is scanning, identifying opportunities in the external business environment such as signals and trends. Scanning can be done quickly when knowledge is well-coded and abstract, whereas, opportunities will be missed if scanning is done slowly. Second, problem-solving means to find solutions to problems which are both well identified and defined. The third cycle is an abstraction that is generalizing the application of new codified knowledge to a larger spectrum of applications. Fourth is diffusion, sharing of new knowledge created within groups or organizations. Fifth is absorption, means to integrate new knowledge into the learning cycle. Lastly, the impact, the relationship between abstract knowledge and its real practice. The order above does not need to run linearly. All of which can be run at the same time so that some could be developed simultaneously. The Boisot model of knowledge dynamics remains more abstract than other models and can be used as a complement to understanding the dynamics of knowledge within an organization (Boisot, 1999 in Bratinu \& Orzea 2010).

Soo et al., (2004) offered a relatively different approach compared to the previous four approaches and is relatively simple by taking the input-process-output perspective. Input is the stage of the source of knowledge where the creation of knowledge is derived from the dynamics of the external environment. The next stage of the process is the stage that knowledge and information are used to find solutions and take decisions on the problems faced. Last but not least, at the output stage there is an innovation that the impact of the innovation can be perceived at the organizational level. Although the research tried to display a model that was relatively different from the previous models, the research was in the same basic argument when it came to the model of knowledge creation. They realized the potential of "bounded rationality" in each individual so that they preferred to place the organization, not as an information processing engine that serves as a "composer" and performs the tasks assigned. In other words, the organization is limited to be an "engine" of information retrieval that process it from the environment to solve problems and adapt to the environment based on the predetermined goals. 
They all agree that the creation of knowledge will be better if it is conceptualized as a dialectical thinking process in which various contradictions are synthesized through the dynamic interaction among individuals, organizations, and the environment. By placing the company as a dialectical organ, the strategy and its organization must be re-examined as a manifestation of the synthesis and transcending process of the organization itself rather than from the logical analysis of the structure or action. Nonaka \& Toyama (2003) are believed to place the organization as organic integration that was conceptualized as an integral in a movement capable to transcend time, space, and organizational boundaries to create a living organism.

\section{CONCLUSION}

As a bundle of resources, understanding the organization of resource-based view approach is also relevant to the competitiveness of an organization. Dynamic capabilities which are a derivative concept of resource-based view organization increasingly shows its contribution when the dynamics of the environment of an organization is increasing. Along with the increasingly dominant role of knowledge in relation to the competitive advantage of an organization, the creation of dynamic capabilities from the perspective of knowledge becomes important to be considered with various arguments that have been discussed by some researchers.

Since the dynamic capabilities are an integral part of the strategic management process (strategy creation) and that the strategy chosen by the organization is generally a growth strategy, there is a linkage between strategy with activities related to knowledge in the organization. In other words, if an organization chooses a growth strategy, there will be several choices of activities related to knowledge such as knowledge protection, knowledge creation, or knowledge discarding. The linkage among dynamic capabilities, growth strategy, and the creation of knowledge is still theoretical. Therefore, it is expected that, in the future, there is a more empirical discussion focusing on how significant the impact or influence of that relationship or even the contribution of the three concepts.

\section{REFERENCES}

1. Acs, Z. J., \& Armington, C. (2006). Entrepreneurship, Geography and American economic growth. New York: Cambridge University Press.

2. Ahenkora, Kwaku \& Adjei Esther, 2012. A Dynamic Capabilities Perspective on the Strategic Management of an Industry Organization. Journal of Management and Strategy. Vol.3. No.3.

3. Barney, J.B. 1991. Firm Resources and Sustained Competitive Advantage. Journal of Management. (17)1. P.99-121.

4. Barney, J.B. 1991. The Resource Based View of Strategy: Origins, Implications, and Prospects. Editor of Special Theory Forum in Journal of Management, 17:97-211.

5. Barney, Jay. B, \& Clark, Derlwyn, N, 2007. Resourced Based Theory: Creating \& Sustaining Competitive Advantage. Oxford University Press.

6. Bratianu Constantin \& Orzea Ivona. 2010. Organization Knowledge Creation. Management Marketing for Knowledge Society. Vol.5, No.3.P 41-62

7. Brown, J.S \& P Duguid. 1991. Organizational Learning and Communities of Practice: Towards a unifying view of working, learning and innovation. Organization Science, 2(1): 40-57.

8. Capeda, G \& D Vera. 2007. Dynamic Capabilities and Operational Capabilities: A Knowledge Management Perspective. Journal of Business Research.60 (5).426-437.

9. Castro, Gregorio Martin De, et.al. 2007. Knowledge Creation Process: Theory and Emipirical Evidence from Knowledge-Intensive Firms. Palgrave Macmillan

10. Chen Der Chao \& Huang-Lung Huang.2013. Knowledge Creating theory in retrospect and prospect. Knowledge Management Research \& Parctice.11.P.405-409. 
11. Chen Der Chao \& Huang-Lung Huang.2013. Knowledge Creating theory in retrospect and prospect. Knowledge Management Research \& Parctice.11.P.405-409.

12. Cohen, W \& D Levinthal, 1990. Absorbtive capacity: A New perspective on learning and innovation. Adminsitrative Science Quarterly,35 (1).128-52.

13. Easterby-Smith, M., Lyles, M. A., \& Peteraf, M. A. 2009. Dynamic capabilities: Current debates and future directions. British Journal of Management, 20: S1-S8.

14. Ferdinand, J.M et.al. 2004. Dynamic Capabilities: Tracking the development of a concept, in proceedings of Organizational Learning, Knowledge and Capabilities, Innsbruck 2-3 April 2004. Austria.

15. Glisbi Martin \& Nigel Holden. 2003. Contextual Constraints in Knowledge Management Theory: The Cultural Embeddedness of Nonaka's Knowledge-Creating Company. Knowledge and Process Management. Vol 10.1.P 29-39.

16. Gorman, Margareth De Lanny, 2004. Creating Organization Knowledge during Transformational Change: A Multi Site Case Study Using An Action Theory Approach. Disertation. The George Washington University.

17. Gourlay, Stephen. 2004. Knowing as Semiosis: Step towards a Reconceptualization of 'tacit knowledge'. Dalam Tsoukas Haridimos dan Nikolaos Mylonopoulos.(Editor). Organizations as Knowledge System. Palgrave Macmillan.

18. Gilbert, B. A., McDougal, P. P., \& Audretsch, D. B. 2006. New venture growth: A review and extension. Journal of Management, 32 (6).P. 926-950.

19. Grant, R. 1996. Toward a knowledge-based theory of the firm. Strategic Management Journal, 17, Winter special issue.109-122.

20. Grant, R. M, 1991. The Resource-based Theory of Competitive Advantage: Implications for Strategy Formulation. California Management Review, Spring: 114-35

21. Haefliger Stefan \& Georg Van Krogh 2004.Knowledge Creation in Open Source Software Development. Dalam Tsoukas Haridimos dan Nikolaos Mylonopoulos.(Editor). Organizations as Knowledge System. Palgrave Macmillan.

22. Heffner, Michael Clifford, 2006. Knowledge Management For Technological Inovation for Organizations: The Fusion Process For Creating Intellectual Capital. Disertation. University Of Meryland. University College.

23. Ichijo, Kazuo.2006."Strategic Management of Knowledge-Based Competence: Sharp Corporation" dalam Takeuchi Hirotaka \& Tsutomu Shibata (Ed). Japan Moving Toward a More Advanced Knowldge Economy: Advance Knowledge-Creating Companies. Washington DC. World Bank Institute.

24. The Strategic Management Knowledge.in Knowledge Creation and Management: New Challenges for Managers (2007). P.121-145.Oxford University Press.

25. Keki, loana Ch. 2008. Creating a Lesson Learned Knowledge Management System For The Egnatia Motorway Company. Thesis. University Of London.

26. Kianto Aino \& Ritala Paavo. 2010. Knowledge-Based Perspective on dynamic capabilities dalam Strategic Reconfiguration \& Building Dynamic Capabilities in Rapid Innovationbased Industries. Edward Elgar. UK.

27. Leonard-Barton, D. 1992. Core capabilities and core rigidities: A paradox in managing new product development. Strategic Management Journal: 111-125.

28. Leonard-Barton. D.1995. Wellsprings of Knowledge. Building and sustaining the sources of innovation, Boston. Harvard Business School Press.

29. Lewin Arie $Y$ dan Silvia Massini. 2004. Knowledge Creation and Organizational Capabilities of Innovating and Immitating Firms. Dalam Tsoukas Haridimos dan Nikolaos Mylonopoulos. (Editor). Organizations as Knowledge System. Palgrave Macmillan.

30. March, J.G. 1991. Exploration and exploitation in organization learning. Organization Science, 2 (1).101-23

31. Mc Carthy, Ian \& Brian Gordon, 2010. Leveraging dynamic capabilities: a contingent management control system approach. Edward \& Elgar.

32. Nelson, R.R. 1991. Why do firms differ and why does it matters?. Strategic Management Journal,12 (1),61-75. 
33. Nielsen, A. 2006. Understanding dynamic capabilities through knowledge management. Journal of Knowledge Management, 10(4): 59-71.

34. Nissen, Mark E. 2006. Harnessing Knowledge Dynamic: Principled Organizational Knowing \& Learning. IRM Press.

35. Nonaka, I, 1994.A Dynamic Theory of Organizational Knowledge Creation. Organization Science 5 (1).14-37.

36. Nonaka I \& Takeuchi, H, 1995. The Knowledge Creating Company. Oxford University Press. New York.

37. Nonaka, I, Toyama R and Toru Hirata, 2008. Managing Flow: A Process Theory of the Knowledge-Based Firm. Palgrave Macmillan.

38. Parayitam Satyanarayana, 2010. Economic of Resource Based and Dynamic Capabilities view: A Contemporary Framework. Academy of Strategic Management Journal. Volume 9, Number 1.

39. Peteraf, M.A,1993. The Cornerstones of Competitive Advantage: A Resource-based View. Strategic Management Journal,14:179-91.

40. Robbins, Stephen P. 1990. Organization Theory: Structure, Design and Applications. Prentice hall. New Jersey USA.

41. Salajeghe, Sanjar et.al. 2014. Analysis of the role of quality management in creating knowledge management value chain. International Journal of Academic Research in Business and Social Research.

42. Sawidji, Widoatmodjo, 2009. Remodeling the Business. Elex Media Komputerindo.

43. Sher, P \& V Lee. 2004. Information technology as a facilitator for enhancing dynamic capabilities through knowledge management, Information \& Management, 41(8): 933-44.

44. Simon, A., 2010. Resources, Dynamic Capabilities and Australian Business Success. Journal of Global Business and Technology, Vol.5 No.2, 13-30.

45. Soo, et.al. 2004. The Role of Knowledge Quality in Firm Performance. Dalam Tsoukas Haridimos dan Nikolaos Mylonopoulos. (Editor). Organizations as Knowledge System. Palgrave Macmillan.

46. Teece, D. J. 2007. Explicating Dynamic Capabilities: The nature and microfoundations of (sustainable) enterprise performance. Strategic Management Journal, 28: 1319-1350.

47. Tseng Mei Shu \& Pei Shan Lee, 2012. The effect of Knowledge management capability and dynamic capability on organizational performance. Journal of Enterprise Information Management. Vol 27.No.2.P.158-179.

48. Winter, S. G. 2003. Understanding dynamic capabilities. Strategic Management Journal, 24: 991-995.

49. Wheelen D T. \& Hunger, D.2005. Strategic Management. Prentice Hall.

50. Zollo, M., \& Winter, S. G. 2002. Deliberate learning and the evolution of dynamic capabilities. Organization Science, 13(3): 339-351. 